\title{
An Application of Integrated Methodology in the Determination of Ergonomic Product Design Requirement
}

\author{
Hilma Raimona Zadry*, Lusi Susanti, Dina Rahmayanti, Fikrah Islami \\ Department of Industrial Engineering, Faculty of Engineering, University of Andalas, \\ Kampus Limau Manis, Pauh, Padang 25163, West Sumatera, Indonesia
}

\begin{abstract}
Spinal Board is one of the first aid evacuation equipment used in emergency medical service acts with the purpose to sustaining life of the accident victim before finally getting further treatment from medical personnel. However, problems with ineffectiveness, inefficiency and discomfort of existing spinal board on the market are frequently found. This study demonstrates the applicability of integrated methodology in determining the design requirement for an ergonomic spinal board. The methodology was derived from multidisciplinary approaches consist of quality function deployment (QFD), Kano model, theory of inventive problem-solving (TRIZ), and failure mode effect analysis (FMEA). The Kano model was used to investigate the customer satisfaction needs (CSNs). Then, the CSNs was processed using QFD method in the House of Quality (HoQ) matrix to identify the critical ergonomic design areas and the key problems in implementing the design. The TRIZ method solves the problems in order to provide solutions for innovative product design. It provides the design team with a methodical way of finding the causes and effects of failures before the design is finalized. In performing an FMEA, the product and/or production system is examined for all the ways in which failure could possibly occur. This study has generated a design requirement for ergonomic spinal board which is able to accommodate customer's expectations and needs. Thus the integrated methodology has indicated promising empirical findings in determining design requirement for ergonomic product with more concrete evidence.
\end{abstract}

Keywords: Integrated Methodology, Design Requirement, Ergonomic, Product Design.

\section{INTRODUCTION}

The most critical factor in the initial process of product development is product design [1]. The success of product design can be achieved through improving the customer satisfaction and delivering inventive and advanced product to the customers. Most of product designers and companies are normally focus on functionality, quality and cost, which have long been the most important factor in product design [2].

*Email Address: hilma@ft.unand.ac.id
Thus, sometimes, the design cannot satisfy all user expectation and ergonomics in the design process. Overall stages of product development usually are handled by engineering specialist. The absence of ergonomist for example may result in undesirable product design [3].

However, in recent years, research in the field of ergonomics and design have shown that the function, quality and cost of the product were not the key determinant of customer satisfaction. Customer satisfaction is also determined by other design elements 
such as safety, comfort, usability and visitor attraction, emotion, appeal and individuation [2]. Quality and ergonomics aims to meet the demands of customers. A high-quality product can be conceded as an ergonomic product because it is designed in accordance with the human capabilities and limitations [4]. Determination of the anthropometric data that will be used also affects the ergonomics designed products. To enhance safety and comfort, design of equipment and facilities should take into account anthropometric differences, because various factors have been shown to influence anthropometric data such as ethnicity, genders, and occupation. Failure to do so will imply in the less safe and comfort of a product [5].

Previous study has been conducted using various kinds of approaches to design an ergonomic product. Nagamachi [6] noted that Kansei engineering method as an ergonomics and consumer-oriented technology for producing a new product. Sagot et al. [7] contributed a number of methodological and theoretical indicators concerning the contribution of ergonomists to the execution of design projects of new products. Then, Pelt and Hey [8] discusses the use of theory of innovation problem solving (TRIZ) together with human-centered design (HCD), a design methodology evolved for consumer product development. Among those approaches, quality function deployment (QFD) is a methodology that is most widely used by researchers in a product design process. It has applied in determining the design requirement of various products [4, 9-14].

Subsequent study has begun to integrate QFD method with other methods or approaches to improve the product design process. A study by Hsiao [15] addressed a concurrent customer-oriented design method for developing a new product. The study integrated the techniques of QFD, failure mode and effect analysis (FMEA), design for assembly (DFA), and analytic hierarchy process (AHP) such that the total quality of the product can be managed. Raharjo et al. [16] proposed a generic network model by exploiting QFD potentials using the analytic network process (ANP) approach, which can be used to assist QFD practitioners in accurately quantify their subjective judgments and experience in a systematic fashion and it can take into account other important factors in the product design context, such as the new product development risk. Then, Hashim and Dawal [17] integrated the Kano Model and QFD to improve the school workshop's workstation design for adolescent in terms of ergonomic and users need. The study was successfully able to prioritize the modification elements to be implemented into the new ergonomically designed workstation. Recent study by Zhang et al. [2] proposed a multidisciplinary approach to improve the product design process in order to give a better product design. They integrated the method of identification of customer satisfaction needs (CSNs), the House of Quality (HoQ) chart of QFD, TRIZ and fuzzy group decision-making theory for ergonomic product innovative design and evaluation.

This study demonstrates the applicability of integrated methodology consist of QFD, Kano model, TRIZ, and FMEA in determining the design requirement for an ergonomic spinal board as the case study. The Kano model was used to investigate the Customer Satisfaction CSNs. Then, the CSNs was processed using QFD method in the HoQ matrix to identify the critical ergonomic design areas and the key problems in implementing the design. The TRIZ method solves the problems in order to provide solutions for innovative product design. It provides the design team with a methodical way of finding the causes and effects of failures before the design is finalized. In performing an FMEA, the product and/or production system is examined for all the ways in which failure can occur. Those methods translate the needs of ergonomic spinal board users into design requirements.

\section{KANO MODEL}

The Kano model of customer satisfaction [18] can identify which requirements of a product or service bring more than proportional satisfaction to customers. Also, it identifies which requirements don't bring satisfaction when present, but bring dissatisfaction when they are not met [19]. Kano model in this study is used to classify customer requirements into five categories: must-be $(M)$, one-dimensional $(\mathrm{O})$, attractive $(\mathrm{A})$, and indifferent $(\mathrm{I})$, based on respondents 'opinion on the questionnaire. The goal is to know the priority of customer requirements that must be met by the product. Must-be attributes are expected by the customers and they lead to extreme customer dissatisfaction if they are absent or poorly satisfied, one-dimensional attributes are those for which better fulfillment leads to linear increment of customer satisfaction, attractive attributes are usually unexpected by the customers and can result in great satisfaction if they are available, and indifferent attributes are those that the customer is not interested in the level of their performance [20].

\subsection{Kano Questionnaire Development}

The Kano questionnaire was constructed by firstly interview the volunteers from the Indonesian Red Cross and the rescue team of Padang, West Sumatera. They gave their opinions regarding the requirements for designing the ergonomic spinal board. Those requirements and data collected from previous study [21] regarding ergonomic consideration about spinal board design were included in the questionnaire. 33 participants from medics, Red Cross, Ambulance Unit Medical Officer and rescue team of Padang, West Sumatera completely answered and returned the Kano questionnaires. Cronbach alpha values for the questionnaire were 0.734 to 0.748 which means the questionnaire is reliable to be used in this study. According to Piaw [22], the acceptable value of Cronbach alpha is 0.65 to 0.95 .

\subsection{Kano Questionnaire Result}

Data analysis was treated by SPSS 22.0 software. All 
qualities were measured and classified into four categories; Must-be (M), Attractive (A), Onedimensional $(\mathrm{O})$ and Indifferent $(\mathrm{I})$. These four categories are separated into two condition; better and worse, based on these equations:

Customer Satisfaction $=\frac{A+O}{A+O+M+I}$

Customer Dissatisfaction $=\frac{O+M}{A+O+M+I}$

Based on above equations, it was easier to identify whether qualities offered will fulfil user satisfaction or prevent the user from dissatisfaction. Calculating CS and $\mathrm{CD}$ values can reveal the average impacts of each quality provided to customer feeling of satisfaction [23]. Table 1 show the recapitulation of customer requirements for spinal board based on Kano Model.

Table 1. The recapitulation of customer requirements for spinal board based on Kano Model

\begin{tabular}{|c|c|c|c|c|}
\hline No. & Customer Requirement & $\begin{array}{l}\text { Kano } \\
\text { Cate- } \\
\text { gory } \\
\end{array}$ & CS & CD \\
\hline 1 & $\begin{array}{l}\text { Spinal board is flat, not slippery } \\
\text { and able to withstand the weight } \\
\text { of the victim }\end{array}$ & M & 0.424 & 0.788 \\
\hline 2 & $\begin{array}{l}\text { The shape and dimensions of } \\
\text { the spinal board does not change } \\
\text { the evacuation procedures } \\
\text { sninal board covered with thin }\end{array}$ & M & 0.333 & 0.576 \\
\hline 3 & $\begin{array}{l}\text { and soft material fitted with the } \\
\text { curvature of the spine }\end{array}$ & M & 0.303 & 0.394 \\
\hline 4 & $\begin{array}{l}\text { Spinal board does not have any } \\
\text { sharp or angular side }\end{array}$ & M & 0.364 & 0.758 \\
\hline 5 & $\begin{array}{l}\text { Straps, head and neck brace can } \\
\text { be attached firmly to the spinal } \\
\text { board to restrain the movement } \\
\text { of the victim }\end{array}$ & M & 0.333 & 0.636 \\
\hline 6 & $\begin{array}{l}\text { Spinal board is lightweight, has } \\
\text { good buoyancy and can be } \\
\text { penetrated by X-rays }\end{array}$ & M & 0.424 & 0.455 \\
\hline 7 & Spinal board can be folded & A & 0.485 & 0.303 \\
\hline 8 & $\begin{array}{l}\text { The fold of spinal board is flat, } \\
\text { hollow and powerful }\end{array}$ & M & 0.364 & 0.424 \\
\hline 9 & $\begin{array}{l}\text { Straps, head and neck brace of } \\
\text { Spinal board lined are mounted } \\
\text { on a semi-permanent basis }\end{array}$ & M & 0.303 & 0.364 \\
\hline 10 & $\begin{array}{l}\text { Straps, head and neck brace of } \\
\text { spinal board are coated by soft } \\
\text { material }\end{array}$ & M & 0.242 & 0.455 \\
\hline 11 & $\begin{array}{l}\text { A buffer on the spinal board side } \\
\text { lined with a soft material and } \\
\text { anti-slip }\end{array}$ & $\mathrm{O}$ & 0.333 & 0.394 \\
\hline 12 & $\begin{array}{l}\text { The size of the straps, head and } \\
\text { neck brace can be adjusted }\end{array}$ & M & 0.333 & 0.727 \\
\hline 13 & $\begin{array}{l}\text { Valves on the straps have a } \\
\text { double lock and is made of a } \\
\text { strong and lightweight material }\end{array}$ & $\mathrm{O}$ & 0.394 & 0.485 \\
\hline 14 & $\begin{array}{l}\text { Spinal board has a buffer to the } \\
\text { vertical position and can be } \\
\text { combined with another stretcher }\end{array}$ & M & 0.438 & 0.688 \\
\hline 15 & $\begin{array}{l}\text { Spinal board, straps, neck and } \\
\text { head brace are made of material } \\
\text { that is resistant porous and } \\
\text { strong }\end{array}$ & M & 0.424 & 0.758 \\
\hline
\end{tabular}

\begin{tabular}{|c|c|c|c|c|}
\hline 16 & $\begin{array}{l}\text { Spinal board, straps, neck and } \\
\text { head brace are resistant to water } \\
\text { and sunlight }\end{array}$ & $\mathrm{M}$ & 0.455 & 0.606 \\
\hline 17 & $\begin{array}{l}\text { Spinal board, straps, neck and } \\
\text { head brace can be easily } \\
\text { cleaned, treated and quick- } \\
\text { drying }\end{array}$ & M & 0.485 & 0.545 \\
\hline 18 & $\begin{array}{l}\text { Spinal board has a variety of } \\
\text { colors }\end{array}$ & M & 0.394 & 0.697 \\
\hline 19 & $\begin{array}{l}\text { Spinal board, straps, neck and } \\
\text { head brace meets the standard of } \\
\text { Emergency Medical Services }\end{array}$ & M & 0.273 & 0.727 \\
\hline 20 & $\begin{array}{l}\text { The booking process of spinal } \\
\text { board is easily and quickly }\end{array}$ & $\mathrm{M}$ & 0.364 & 0.758 \\
\hline 21 & $\begin{array}{l}\text { Spinal board has better quality } \\
\text { than that are commonly used }\end{array}$ & $\mathrm{M}$ & 0.424 & 0.485 \\
\hline 22 & The price is affordable & $\mathrm{O}$ & 0.303 & 0.545 \\
\hline
\end{tabular}

\section{QUALITY FUNCTION DEPLOYMENT (QFD) - HOUSE OF QUALITY (HoQ) PHASE 1}

Quality Function Deployment (QFD) is a significant methodological approach to enhance customer satisfaction and reduce the product costs and development cycle time [21]. QFD allows the development team to define clearly the wishes and needs of the users then systematically evaluate the impact of any design proposal on the product to meet the user needs [22]. Hence, this study used QFD method to investigate the customer and technical requirements for designing ergonomics spinal board. By using the Kano model and integrating it in the QFD the design team can enhance the understanding of customer needs, leading to superior product design [17].

The collected data of Kano questionnaires were processed using QFD design through House of Quality (HoQ). HoQ consists of several activities supported by various tables and matrices. The basic idea is to translate customer requirements into the product design requirements in order to increase customer satisfaction [3, 16, and 25]. The HoQ was developed in two phases, HoQ phase 1 to determine the priority of technical requirements and $\mathrm{HoQ}$ phase 2 to determine the priority of design requirements.

HoQ phase 1 was developed using the following steps:

a. Determine the customer requirements and the customer important ratings

Customer requirements which are included into these category of Kano: attractive, one-dimensional or must-be, then used in the HoQ matrix. This is due to these categories of customer requirements can increase user satisfaction if fulfilled.

b. Translating customer requirements into measurable technical requirements

Determination of the technical requirements aimed to know the technical terms that is required by the spinal board. The technical requirements in HOQ matrix is obtained from the interview with expert by consultation and discussion with experts in the respective products related to material and manufacturing. 
c. Determine the relationship between the customer requirements and the technical requirements

d. Determine the interactions between the technical requirements

The purpose of determining the relationship between the technical requirements is to look at the positive or negative relationship between them, so that if there is a contradiction, it can be identified and solved. This is where TRIZ will be used.

e. Determine the priority of the technical requirements.

\section{THEORY OF INVENTIVE PROBLEM SOLVING (TRIZ)}

The use of TRIZ method aims to find alternative solutions of the contradiction between two technical requirements without having to sacrifice one of them. The steps of determining a solution by this method are as follows:

a. Identify the technical requirements that contradict on the HOQ matrix then assign one of the technical requirement as the parameter that want to repair and other technical requirement as the parameters that have been adversely affected as a result of such improvements.

Based on HoQ matrix, there are five contradictions on the spinal board technical requirements, namely:

- Contradiction between design modification and the selection of manufacturing method

- Contradiction between the selection of hinge system and the selection of manufacturing method

- Contradiction between features addition and the manufacturing method

- Contradiction between the selection of quality materials and the low price material

- Contradiction between features addition and the low price material.

b. Determine TRIZ inventive principles based on contradiction matrix selected.

c. Choose the most suitable TRIZ inventive principles and formulate the specific solutions to the technical requirement based on the selected principle.

Based on these principles, the solutions are as follows:

- Solution for contradiction 1: The replacement of mechanical method for the ergonomic design of the spinal board and features.

- Solution for contradiction 2: The use of hinge system with the local quality level on the spinal board.

- Solution for contradiction 3: The unification of the manufacturing method for spinal board and features.

- Solution for contradiction 4: The use of qualified composite materials for spinal board features. Solution for contradiction 5: The use of lightweight materials for spinal board additional features such as pads, straps, head and neck brace.

\section{QUALITY FUNCTION DEPLOYMENT (QFD) - HOUSE OF QUALITY (HoQ) PHASE 2}

\begin{abstract}
Design matrix in HoQ phase 2 was made to convert the entire technical requirements into design requirements. The design matrix was derived from the technical requirements which are not contradicted to each other, while the technical requirements which are contradicted to each other replaced with specific solutions obtained by TRIZ method. The steps in developing the design matrix are:
\end{abstract}

a. Determine the design requirements

Design requirements were obtained from the discussions with the engineering and manufacturing experts as well as the team from disaster management and Red Cross of Padang, West Sumatera, who know about the principles of spinal board use and the prevention of secondary injury to the spine.

b. Determine the relationship between the technical requirements and the design requirements

c. Determine the priority of the design requirements

The process of determining the priority value of design requirements was done by previously calculating the percentage of absolute important ratings from the relationship between the technical requirements and the design requirements.

\section{FAILURE MODE EFFECT ANALYSIS (FMEA)}

FMEA can assist the designer in finding the causes and effects of failure before the product design has been finished [15]. This method is suitable for obtaining the priority factors that could cause failures and losses in the production process. Determination of the key factors causing the failure was conducted to minimize the possibility of failure during the production process or spinal board design has been in the hands of users.

The first step in this method is to identify the failure that may occur based on spinal board design requirements. Then, the causes and the grade of failure modes are identified. Failure at the first grade (extreme serious) and the second grade (very strong) are set as the key factors causing the failure [15]. The final step is to formulate the strategy to fix the failures. This step is also conducted through discussion with engineering and disaster management experts. The FMEA results then deployed in the step of design requirement determination of the HoQ.

\section{ANALYSIS}

The purpose of spinal board design development is to determine the spinal board design requirements which are better than the spinal board design requirement derived from previous study [21] and commonly used spinal board product. Comparisons are made between the spinal board design requirements from previous study [21] 
which only used the QFD method and the design requirements obtained by using the integrated methodology of Kano model, QFD, TRIZ and FMEA. The comparisons showed that the design requirements obtained from the integrated methodology have advantages in the consideration of ergonomic factors. The ergonomic requirements are in terms of comfort and security of victims and evacuation team when using spinal board.

In addition, based on the design requirement, spinal board are made of fiberglass material that is much more resistant to water and heat and is much lighter when compared with the commonly used spinal board. Every part of spinal board is covered by soft material that the shape and size can be adjusted so it cannot change the position of the victim's body during the evacuation process. The head and neck brace, straps and pads of the spine are made adjustable and can be mounted on the spinal board in semi-permanent basis. It can also be installed at the time the victim had been on the board. This will certainly save the time of spinal board installation setup during the evacuation process. It means the flexibility of this new ergonomic spinal board design is better than those from previous study [21].

Meanwhile, if viewed from the price side, the price of the spinal board new design spinal board tends to be more expensive compared to those derived from previous study [21] and commonly used spinal board product. This is because it used the composite materials which are easily available in the market though, but the price is slightly more expensive than High-density polyethylene (HDPE). But this can be overcome by reducing the spinal board thickness so that the material used be less but still considers the durability spinal board

\section{CONCLUSIONS}

In this study an integrated methodology consist of Kano model, QFD, TRIZ and FMEA, for determining the design requirements of a new product is applied in designing an ergonomic spinal board. Some conclusions are drawn:

a. The spinal board design requirements derived from the study are more able to accommodate the user needs and expectation in terms of ergonomics, and quality of the product.

b. The failure in product development can be determined through FMEA method, thus it can minimize the possibility of failure during the production process.

c. The TRIZ method solves the problems in order to provide solutions for contradiction between two technical requirements without having to sacrifice one of them thus can produce the innovative product design.

d. The integrated methodology in ergonomics product design requirements can be applied on other design research to obtain an ergonomic product design, according to the needs and expectations of users, but lack of failure.

\section{ACKNOWLEDGMENTS}

This work was supported by Directorate General for Higher Education of Indonesia under grant Penelitian Unggulan Perguruan Tinggi (PUPT) No. 44/UN.16/UPT/LPPM/2015.

\section{REFERENCES}

[1] C. M. Crawford, New products management (5th Ed.). Boston, Richard D. Irsiaowin Inc. (1997).

[2] F. Zhang, M. Yang, and W. Liu, Comput. Ind. Eng. 76, 60-74 (2014).

[3] J. A. Marsot, Appl. Ergon. 36(2), 185-192 (2005).

[4] K. Bergquist and J. Abeysekera, Int. J. Ind. Ergon. 18, 269-275 (1996).

[5] A. Widyanti, L. Susanti, I. Z. Sutalaksana, and K. Muslim, Int. J. Ind. Ergon. 47, 72-78 (2015).

[6] M. Nagamachi, Appl. Ergon. 33, 289-294 (2002).

[7] J. C. Sagot, V. Gouin, and S. Gomes, Safety Sci. 41, 137-154 (2003).

[8] A. V. Pelt and J. Hey, Procedia Engineering, 9, 688-693 (2011).

[9] L. F. M. Kuijt-Evers, K. P. N. Morel, N. L. W. Eikelenberg, and P. Vink, Appl. Ergon. 40, 519-526 (2009).

[10] C. C. Usma-Alvarez, A. Subic, M. Burton, and F. K. Fuss, Procedia Engineering, 2, 2749-2755 (2010).

[11] J. F. Cardoso, N. C. Filho, and P. A. C. Miguel, Food Qual. Prefer. 40, 180-190 (2015).

[12] H. R. Zadry, T. Y. Mustafa, D. Rahmayanti, D. Meilani. Alternative Design of Ergonomic Walk Learning Tool for Toddlers Using Quality Function Deployment (QFD). Proceedings of the Joint International Conference APCHIErgoFuture-PEI-IAIFI, (2014) October 22-25; Bali, Indonesia.

[13] H. R. Zadry and D. A. Irfansyah. Investigation of Customer and Technical Requirements for Designing an Ergonomics Notebook Soft Case using Quality Function Deployment (QFD) Approach. Proceedings of the 2nd International Conference on Industrial Engineering, Management Science and Applications, (2015) 26-28 May; Tokyo, Japan.

[14] H. R. Zadry, L. Susanti, and D. Rahmayanti, Int. J. Occup. Saf. Ergon. DOI: 10.1080/10803548.2016.1156843 (2016).

[15] S. W. Hsiao, Int J Ind Ergon. 29, 41-55 (2002).

[16] H. Raharjo, A. C. Brombacher, and M. Xie, Comput. Ind. Eng. 55, 253-278 (2008).

[17] A. M. Hashim and S. Z. Dawal, Procedia - Social and Behavioral Sciences. 57, 22-32 (2012).

[18] N. Kano, N. Seraku, F. Takahashi, and S. Tsuji, JSQC. 14(2), 3948 (1984).

[19] G. Tontini, Total Qual. Manage. 18(6), 599-612 (2007).

[20] Q. Xu, R. J. Jiao, X. Yang, M. Helander, H. M. Khalid, and A. Opperud, Design Stud. 30(1), 87-110 (2009).

[21] H. R. Zadry, D. Rahmayanti, L. Susanti, and D. Fatrias, Procedia Manufacturing, 3, 4673-4680 (2015).

[22] C. Y. Piaw, Asas Statistik Penyelidikan, (Kaedah dan Statistik Penyelidikan, Kuala Lumpur, McGraw Hill (Malaysia) (2006).

[23] T. Wang and P. Ji, Int. J. Qual. Reliab. Manag. 27(2), 173-84 (2010).

[24] E. S. Jaiswal, A Case Study on Quality Function Deployment (QFD), India, Mewar University (2012).

[25] X. Lai, M. Xie, K. C. Tan, and B. Yang, Comput. Ind. Eng. 54, 202-214 (2008). 